Carl Goodyear Grant/research support from: AstraZeneca, BMS, Celgene, Janssen, MedAnnex, Pfizer and UCB, Speakers bureau: Abbvie DOI: 10.1136/annrheumdis-2019-eular.1802

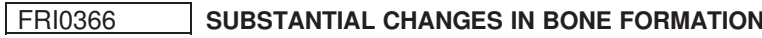 REGULATORS BIOMARKERS IN EARLY AXIAL SPONDYLOARTHRITIS - ROLE OF TNF INHIBITORS}

Elise Descamps ${ }^{1}$, Anna Moltó $^{1}$, Didier Borderie ${ }^{2}$, Rik Lories $^{3}$, Corinne Miceli Richard ${ }^{1}$, Christian Roux ${ }^{1}$, Karine Briot ${ }^{1}{ }^{1}$ Hôpital Cochin, Rheumatology, PARIS, France; ${ }^{2}$ Hôpital Cochin, Biology, PARIS, France; ${ }^{3} \mathrm{KU}$ Leuven, Skeletal Biology and Engineering Research Center, Leuven, Belgium

Background: The hallmark of advanced axial spondyloarthritis $(\mathrm{SpA})$ is spine ankylosis, due to an excess of bone formation. Our hypothesis was that pathways of bone formation regulators changed over time and that their changes were related to inflammation or use of "anti-inflammatory" drugs (like non-steroidal anti-inflammatory drugs (NSAIDs) and/or Tumor Necrosis Factor inhibitors (TNFi).

Objectives: This prospective study aimed to describe the 5-year serum changes of bone formation regulators markers (sclerostin, bone morphogenetic protein 7 (BMP-7) and Dickkopf-1 (DKK-1)) in early axial SpA and to assess determinants of their changes.

Methods: The DESIR cohort is a prospective, multicentre French study of 708 patients $(34 \pm 9$ years, 58\% HLA B27 positive, BASDAI $45 \pm 20$ ) with early ( $>3$ months and $<3$ years) inflammatory back pain suggestive of axial SpA. Sclerostin, BMP-7 and DKK-1 serum levels were assessed at baseline, two and five years. Change in bone formation regulators over time was analysed using mixed linear models, first in complete-cases and then in available-cases analysis. Determinants of serum biomarkers change were analysed using mixed linear models and we searched for an interaction between time and determinants of serum biomarkers.

Results: Serum levels of each biomarkers at baseline, two and five years are reported in Table 1. Serum BMP-7 significantly increased over time, with a mean of $0.17 \mathrm{pg} / \mathrm{mL}$ per month (Figure $1 \mathrm{~A}$ ). Median relative change of BMP-7 at five years was $53.0 \%$ [IQR $-31.6 \%, 286.8 \%$ ]. Serum BMP-7 levels was undetectable in 337 patients $(59.6 \%)$ at baseline, in 111 patients $(48.0 \%)$ at two years and in 59 patients $(20.2 \%)$ at five years. At baseline, serum sclerostin was significantly correlated with age $(r=0.28, p<0.001)$, weight $(\mathrm{kg})(r=0.10, p=0.007)$, CRP level $(\mathrm{mg} /$ $\mathrm{mL})(r S=-0.14, p<0.001)$, mSASSS $(r=0.08, p=0.03)$, number of syndesmophytes $(r=0.15, p<0.001)$, bone mineral density in hip and lumbar spine $(r=0.19, p<0.001$ and $r=0.18, p=0.001$ respectively). Serum sclerostin significantly increased over time, with a mean of 0.001 $\mathrm{ng} / \mathrm{mL}$ per month (Figure $1 \mathrm{~B}$ ). Median relative change of sclerostin at five years was $14.8 \%[-7.9 \%, 41.4 \%]$. Serum DKK-1 did not significantly vary over time. In multivariate analysis, serum BMP-7 increased with moderate or high disease activity (ASDAS-CRP) $(0.19 \mathrm{pg} / \mathrm{mL}$ per month, $\mathrm{p}=0.01$ ), in men $(5.3 \mathrm{pg} / \mathrm{mL}, \mathrm{p}=0.004)$ and decreased with the duration of TNFi use $(-0.04$ per month of TNFi use, $p<0.001)$. Unlike in serum BMP-7, there was not a significant interaction between time and determinants of serum sclerostin. In multivariate analysis, serum sclerostin increased with time $(0.001 \mathrm{ng} / \mathrm{mL}$ per month, $\mathrm{p}<0.001)$, age $(0.007 \mathrm{ng} / \mathrm{mL}$ per year, $\mathrm{p}$ $<0.001)$ and in men $(0.05 \mathrm{ng} / \mathrm{mL}, \mathrm{p}=0.001)$ but decreased with the use of TNFi $(-0.037 \mathrm{ng} / \mathrm{mL}, \mathrm{p}<0.001)$, in patients with a $Z$ score $\leq-2$ at at least one site $(-0.036 \mathrm{ng} / \mathrm{mL}, p=0.005)$ and with serum BMP-7 levels $(-0.0006 \mathrm{ng} / \mathrm{mL}$ per unit of serum BMP-7, $\mathrm{p}=0.03)$.

Conclusion: Serum BMP-7 levels significantly increased over time with a rapid and substantial change. Serum sclerostin levels significantly increased over time but to a lesser degree than serum BMP-7. Serum BMP-7 changes were related to the use of TNFi.

Table 1. Serum levels of bone biomarkers over time

\begin{tabular}{lccc}
\hline & SOST $(\mathrm{ng} / \mathrm{mL})$ & DKK-1 $(\mathrm{pg} / \mathrm{mL})$ & BMP-7 $(\mathrm{pg} / \mathrm{mL})$ \\
\hline Baseline & $0.45 \pm 0.18$ & $5413.0 \pm 2370.0$ & $11.0 \pm 27.5$ \\
& & & $2.1[0-15.7]$ \\
Two years & $0.46 \pm 0.15$ & $5621.3 \pm 2571.0$ & $20.3 \pm 19.2$ \\
& & & $16.2[5.2-27.7]$ \\
Five years & $0.51 \pm 0.19$ & $4998.2 \pm 2889.3$ & $20.9 \pm 17.6$ \\
& & & $19.5[7.2-30.6]$ \\
\hline
\end{tabular}

Results are expressed by mean \pm standard deviation and median [IQR]
Figure 1:

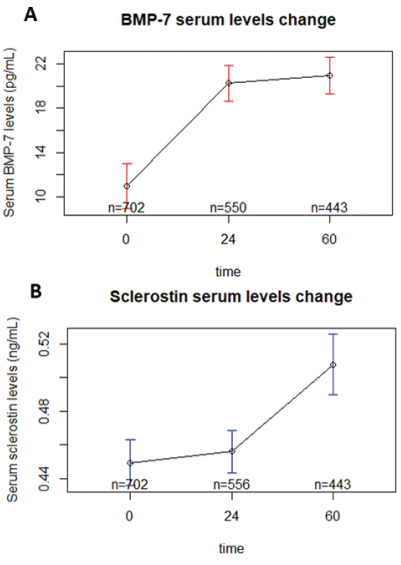

Acknowledgement: This study was supported by a grant from the French Society of Rheumatology (SFR)

Disclosure of Interests: Elise Descamps: None declared, Anna Moltó: None declared, Didier Borderie: None declared, Rik Lories Consultant for: Abbvie, Celgene, Eli-Lilly, Janssen, Merck, Novartis, Pfizer, UCB, Corinne Miceli Richard Grant/research support from: MSD, Pfizer, AbbVie, Biogen, UCB, Novartis, Consultant for: Abbvie, Novartis, BMS, Christian Roux Grant/research support from: Alexion, Amgen, UCB, Karine Briot Consultant for: Karine Briot has received consultancy honoraria and conference fees from UCB, Amgen, Lilly and MSD DOI: 10.1136/annrheumdis-2019-eular.2205

\section{FRI0367 INFLAMMATORY PROCESSES IN EXPERIMENTAL SPONDYLOARTHRITIS ARE ACCOMPANIED BY FORMATION OF ECTOPIC LYMPHOID STRUCTURES IN THE BONE MARROW AND ALTERATIONS IN THE B CELL LINEAGE}

Merlijn Kaaij, ${ }^{1,2}$, Jan Piet van Hamburg ${ }^{1,2}$, Jasper Rip ${ }^{3}$, George Kollias ${ }^{4}$, Dominique Baeten ${ }^{1,2}$, Martijn Nolte ${ }^{5}$, Leonie van Duivenvoorde ${ }^{1,2}$, Sander W. Tas ${ }^{1,2} .{ }^{1}$ Amsterdam UMC, University of Amsterdam, Amsterdam Rheumatology and immunology Center, Amsterdam, Netherlands; ${ }^{2}$ Amsterdam UMC, University of Amsterdam, Department of Experimental Immunology, Amsterdam, Netherlands; ${ }^{3}$ Erasmus MC, Pulmonary Medicine, Rotterdam, Netherlands; ${ }^{4}$ Biomedical Sciences Center "Alexander Fleming", Division of Immunology, Vari, Greece; ${ }^{5}$ Sanquin Research and Landsteiner Laboratory, Amsterdam UMC, UVA, Department of Molecular and Cellular Hemostasis, Amsterdam, Netherlands

Background: Tumour necrosis factor (TNF) is important in immune-mediated inflammatory diseases such as spondyloarthritis (SpA). SpA patients have extensive angiogenesis in inflammatory and bone forming regions. Transmembrane (tm)TNF-transgenic (tg) mice (1) that overexpress tmTNF develop SpA symptoms, including inflammation, bone destruction and bone formation. Interestingly, these mice also develop lymphoid aggregates in the bone marrow (BM) of the axial and peripheral skeleton.

Objectives: Characterization of lymphoid aggregates in tmTNF tg mouse $\mathrm{BM}$ in the context of angiogenesis and bone formation.

Methods: Ankles, femora, tibiae, vertebrae and spleens from tmTNF tg mice and wild-type (WT) littermates (6 weeks, 12 weeks, and 8 months old; $\mathrm{n}=5$ per age per group) were dissected and analyzed by confocal microscopy. In addition, 12 week old mice ( $n=5$ per group) were analyzed by flow cytometry. To study the importance of TNF-R signaling in these processes, tmTNF $\operatorname{tg}$ mice lacking TNF-RI (tmTNF tgxTNF-Rl ${ }^{-/}$) or TNF-RII (tmTNF tgxTNF-RII ${ }^{-1-}$ ) ( $n=4$ per group) were investigated.

Results: Immunofluorescent (IF) evaluation demonstrated that BM of tmTNF tg mice contained extensive lymphoid aggregates, both in the vertebrae and the ankles, but not in the femurs or spleen. IF microscopy demonstrated that the aggregates in the BM contain characteristics of ectopic lymphoid structures (ELS) and consisted of $\mathrm{B}_{2} 2 \mathrm{O}^{+} \mathrm{B}$ cells and FDC-M $1^{+}$follicular dendritic cells that are in close proximity of MECA $79^{+-}$ high endothelial venules (HEVs). Flow cytometric analysis revealed that most $\mathrm{B}^{2} 2 \mathrm{O}^{+} \mathrm{B}$ cells are $\mathrm{IgD}^{+}$naive $\mathrm{B}$ cells and that tmTNF tg vertebrae 